\title{
Does Passion mediate the Effect of Character Strengths on the Resilience of Athletes?
}

\section{¿Media la pasión los efectos de las fortalezas del carácter en la resiliencia de atletas} apasionados?

\section{A paixão medeia os efeitos das forças de caráter sobre a resiliência de atletas apaixonados?}

\author{
Vančáková, $\mathrm{J}^{1}$, Chamarro, A ${ }^{1}$, Martínez-Martí, M.L. ${ }^{2}$ \\ ${ }^{1}$ Universitat Autonoma de Barcelona; Barcelona, España ${ }^{2}$ Universidad Camilo José Cela, Madrid, \\ España
}

\begin{abstract}
This study investigates (a) the relationship between character strengths, passion and resilience in athletes in a sample of Spanish passionate athletes (elite, federated and recreational), and (b) if passion for sport mediates the relationship between character strengths and resilience. Using a cross-sectional design, participants $(\mathrm{N}=480)$ completed measures of character strengths, passion, and resilience. Both Principal Components and Confirmatory Factor Analyses were conducted with character strengths, and five factors were extracted. All character strengths factors related positively to resilience. Harmonious passion (but not obsessive passion) partially mediated the relationship between all character strengths factors and resilience. Strengths and limitations of the study, as well as its implications are discussed
\end{abstract}

Keywords: Personality; Sport psychology; Positive psychology.

\section{RESUMEN}

Este estudio investiga (a) la relación entre las fortalezas del carácter, la pasión y la resiliencia de una muestra de atletas apasionados españoles (élite, federados y recreativos), y (b) si la pasión por el deporte media la relación entre las fortalezas del carácter y la resiliencia. Mediante un diseño transversal, los participantes $(\mathrm{N}=480)$ completaron medidas de fortalezas del carácter, pasión y resiliencia. Se llevaron a cabo un análisis de componentes principales y un análisis factorial confirmatorio con las fortalezas de carácter y se extrajeron cinco factores. Todos los factores de fortalezas del carácter se relacionaron positivamente con la resiliencia. La pasión armoniosa (pero no la pasión obsesiva) medió parcialmente la relación entre todos los factores de fortalezas del carácter y la resistencia. Finalmente, se discuten las fortalezas y limitaciones del estudio, así como sus implicaciones.

Palabras clave: Personalidad; Psicología del deporte; Psicología positiva

\section{RESUMO}

Este estudo investiga (a) a relação entre forças de caráter, paixão e resiliência de uma amostra de atletas espanhóis apaixonados (elite, federados e recreativos), e (b) se a paixão pelo esporte medeia a relação entre forças de caráter e resiliência. Usando um desenho transversal, os participantes $(\mathrm{N}=480)$ completaram medidas de força de caráter, paixão e resiliência. Uma análise de componentes principais e uma análise fatorial confirmatória foram realizadas 


\section{Passion, character strengths and resilience}

com forças de caráter e cinco fatores foram extraídos. Todos os fatores de força de caráter foram positivamente relacionados à resiliência. A paixão harmoniosa (mas não a paixão obsessiva) media parcialmente a relação entre todos os pontos fortes dos fatores de caráter e a resistência. Por fim, são discutidos os pontos fortes e as limitações do estudo, bem como suas implicações.

Palavras chave: Personalidade; Psicologia do esporte; Psicologia positiva

\section{INTRODUCTION}

Sports may become a passionate activity (Vallerand et al., 2003; Vallerand \& Miquelon, 2007). Most athletes use the term passion when referring to their relationship with sports, and in consonance, they love sports and practice for years. Athletes might be so passionate about sport, that it becomes part of their identity: they define themselves as "athletes". Being passionate is important for athletes, as research shows that passionate athletes seem to perform better and feel more satisfied with their lives (e.g., Curran, Hill, Appleton, Vallerand, \& Standage, 2015). Moreover, according to Niemiec (2018), our life passions are related to our interests and character strengths. Each of us chooses the activities we practise in our free time so we can express our particular character strengths. In fact, recent studies have shown that an increase in character strengths and in the use of signature strengths (i.e., character strengths that are most important for the identity of the individual and that are most frequently expressed) was related to an increase in harmonious passion (Dubreuil et al., 2016; Forest et al., 2012). However, the relationship between passion and character strengths in the sports context is unknown.

Furthermore, passion also seems to be related to resilience, at least in the work context (Trépanier, Fernet, Austin, Forest, \& Vallerand, 2014). Resilience is considered a pre-requisite for athletic success (Wagstaff, Sarkar, Davidson, \& Fletcher, 2017). Athletes face many pressures when competing (e.g., expected performance, competitive environment, etc.), and resilience probably allows athletes to thrive under pressure. Nonetheless, there is neither any evidence of the relationship between passion and resilience in the sports context.

Finally, some studies have suggested a positive relationship between character strengths and resilience (Jordan, 2005; Martínez-Martí \& Ruch, 2016; Martínez-Martí, Theirs, Pascual, \& Corradi, 2020; Wong, 1995). Martínez-Martí and Ruch (2016) found that emotional strengths (which included strengths such as zest, love or hope) and strengths of restraint (such as persistence, prudence or self-regulation) were significant positive predictors of resilience over and above sociodemographic variables, positive affect, self-efficacy, optimism, social support, self-esteem, and life satisfaction. However, as far as we know, there are no studies examining the relationship between character strengths and resilience in the sport context.

It is quite common to hear athletes, or their coaches, talk about the need to overcome obstacles (resilience), to enjoy what they are doing (passion) and to be who they really are and develop their potential (character strengths). However, even though character strengths, passion and resilience are relevant constructs for the sport context, and seem to be interrelated, as far as we know there is a lack of studies exploring this relationship in this specific context.

Therefore, in an effort to narrow this gap in the literature, and provide empirical evidence that could guide the design and implementation of future positive interventions in the sport context, we decided to explore the relationship between character strengths, passion, and resilience in athletes, as well as the mediating role of passion on the hypothesized relationship between 


\section{Vančáková, Chamarro, \& Martínez-Martí}

character strengths and resilience in this specific context.

\section{Passion}

Passion is defined as a strong inclination toward a personally, meaningful, and highly valued activity that one loves, finds self-defining, and in which substantial time and energy is invested (Vallerand et al., 2003). As stated in the Dualistic Model of Passion (Vallerand et al., 2003), passion is a dualistic concept (i.e., harmonious passion and obsessive passion), according to the different degree in which a specific activity is internalized in one's identity. A full internalization, i.e., when the person freely chooses to engage in an activity, without either internal or external pressures, will result in a harmonious passion (HP). In HP, the activity is fully integrated into the identity of the individual. The practice of the activity is persistent, flexible, and brings the opportunity to both perform optimally and experience positive outcomes, such as life satisfaction and positive affect. In contrast, in the case of obsessive passion (OP), the integration into the activity is incomplete because internalization is controlled by either internal (e.g., activity-contingent selfesteem) or external (e.g., reinforcement from parents) outcomes. In OP, there is a pressure to engage in a specific activity because that is the main way to obtain responses from others. In OP, the relevance of the activity is disproportionate, controls the person's life and conflicts with other activities in other life domains. As a result, OP leads to a rigid persistence towards the activity and, although is associated with some positive outcomes (e.g., vitality or performance), it may also bring some negative outcomes such as rumination and negative affect (e.g., Curran et al., 2015; Stenseng, Forest, \& Curran, 2015; Young, de Jong, \& Medic, 2015). The Dualistic Model of Passion has been supported in the area of sports in both recreational and competitive contexts (e.g., Chamorro et al., 2020; Raimundi et al., 2019; Vallerand \& Miquelon, 2007).

\section{Character strengths}

Character strengths are positive, morally valued, traits of personality that might be developed by experience and volition (Peterson \& Seligman, 2004). According to Peterson and Seligman (2004), one of the conditions for a personal quality to be considered a character strength is that it should determine a person's coping style and contribute to the fulfilment of a good life. Peterson and Seligman's Values-in-Action (VIA) classification encompasses 24 character strengths that are theoretically grouped in six virtues (i.e., transcendence, humanity, courage, temperance, justice, and wisdom), although research focused on strengths usually group these 24 strengths in five factors that are derived empirically. These five factors are commonly labelled as interpersonal strengths, intellectual strengths, transcendence strengths, emotional strengths, and strengths of restraint (e.g. Martínez-Martí \& Ruch, 2016). Character strengths might act as barriers against misfortune and psychological disorders and might be the key to speeding up recuperation (Peterson, Park, \& Seligman, 2006; Seligman, 2003). Likewise, character strengths are relevant positive predictors of resilience (Martínez-Martí \& Ruch, 2016; Zautra \& Reich, 2012).

\section{Resilience}

Resilience has been conceptualized in the literature in different ways. According to Fletcher and Sarkar (2012, 2013), although the construct has been operationalized in a variety of ways, most definitions involve either, the original conception of resilience as a coping ability embodying the personal qualities that enable an individual to face an adversity, proposed by Connor and Davidson (2003), or the concept of positive adaptation (i.e., a behaviour promoting personal assets, coping processes, and symptoms related to internal well-being), proposed by Luthar, Cicchetti, and Becker (2000). Thus, resilience is a multidimensional concept that includes not just abilities as coping, but also the 


\section{Passion, character strengths and resilience}

personality and temperament of individuals (Hosseini \& Besharat, 2010). Moreover, resilience may vary in different contexts (e.g., work vs. personal relationships) (Connor \& Davidson, 2003), a finding that is relevant for the present study since sport is generally considered a highly demanding context characterized by a never-ending need for adaptation (e.g., Galli \& Vealey, 2008). In that regard, some authors have suggested that resilience in sport should be measured in terms of sport-context behaviours, given that the resilience of a specific person may vary in different contexts, as we just mentioned (Connor \& Davidson, 2003; Ruiz et al., 2012). In the present study, resilience was conceptualized as a coping ability that embodies the personal qualities that allow a person to face an adversity (Connor \& Davidson, 2003), and sustains the positive growth of the individual as a result of overcoming his/her own personal and sport challenges (Sarkar \& Fletcher, 2014). Resilience should play an important role in sport, since its development is linked to well-being and adaptation (García Secades et al., 2014; Roffé, 2016; Sarkar \& Fletcher, 2014). However, little is known on the relationship between resilience, character strengths, and passion in this specific context.

\section{The Present Study}

Since character strengths seem to be related to the kind of activities we are passionate about (Niemiec, 2018), and passion seems to influence our ability to cope with adversity (i.e., resilience) (e.g., Galli \& Vealey, 2008; Vallerand, 2015), it seems plausible that HP mediates the relationship between character strengths and resilience, at least partially. Given that OP is not fully integrated in the identity (Vallerand et al., 2003) of athletes, it is likely that this type of passion does not mediate the relationship between character strengths and resilience. Therefore, since sport is generally considered a highly challenging context that demands constant adaptation, and there is neither any evidence to date on the possible relationship between character strengths, passion, and resilience in this context, nor of the role of passion on the potential relationship between character strengths and resilience, the aim of the present study is to explore the relationship between character strengths, passion, and resilience in passionate athletes, as well as the possible mediating role of (harmonious) passion in this relationship. Accordingly, we define the following hypotheses:

(1) H1: Character strengths, harmonious passion (but not obsessive passion), and resilience are positively interrelated in passionate athletes.

(2) H2: Harmonious passion (but not obsessive passion) mediates (at least partially) the relationship between character strengths and resilience in passionate athletes.

\section{METHODS}

Study Design

The design of the present study is explicative with observed variables (Ato, López \& Benavente, 2013).

\section{Participants}

A convenience sample was used. Initially, a total of 535 Spanish athletes answered the questionnaire. Twenty-seven participants were excluded because of having more than four missing data (i.e., the $5 \%$ of all items), and five participants because of not having expressed permission from their parents. Participants whose mean score of the five passion criterion items was situated at midpoint (4) or above on the sevenpoint Likert scale, were considered to be passionate, which is in line with past research (e.g., Gousse-Lessard, Vallerand, Carbonneau, \& Lafrenière, 2013; Rip, Fortin, \& Vallerand, 2006). According to these rules, 23 additional participants were excluded because of not being passionate.

Thus, the final sample included 480 passionate athletes (335 males, 143 females, and two people who did not specify their gender). Mean age was 26.1 years $\left(S D_{\text {age }}=12.3\right.$, age range: $14-74$ years). Participants had completed their studies at higher 


\section{Vančáková, Chamarro, \& Martínez-Martí}

education (49.2\%), high school education $(45.9 \%)$, primary education $(4.4 \%)$ and $0.6 \%$ undisclosed.

Figures 1 and 2 show the distribution of gender and age in different levels of sport dedication: recreational, federated, and elite athletes. Recreational athletes have experience within local competitions or do not compete. Federated athletes compete in provincial or local sport clubs and schools but not on an international level. Elite athletes were members of national teams or had experience with international competitions.

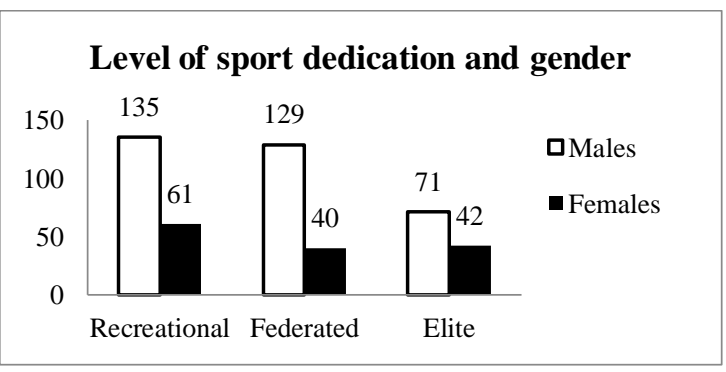

Figure 1. Level of sport dedication and gender.

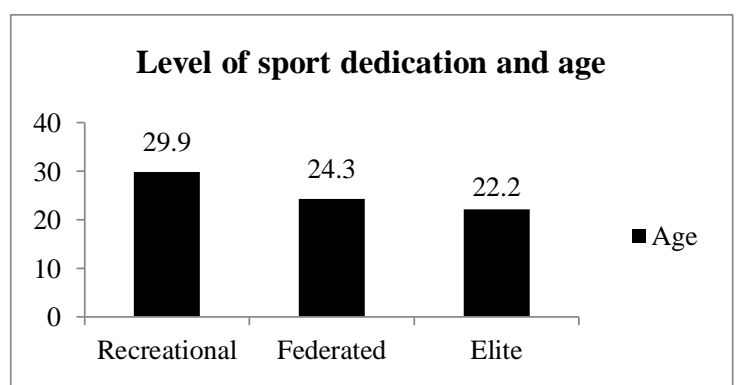

Figure 2. Level of sport dedication and age.

\section{Measures}

The survey consisted of socio-demographic information (gender, age, and education level), level of sport dedication, and the following measures.

The Character Strengths Rating Form (CSRF; Ruch, Martínez-Martí, Proyer, \& Harzer, 2014), which was back-translated to Spanish using the standard procedure. The CSRF is based on Peterson and Seligman's (2004) classification of 24-character strengths. It consists of 24 items rated on a 9-point Likert-type scale, ranging from $1=$ not like me at all to $9=$ absolutely like me. Each item is a definition of one-character strength (e.g., "Bravery (valour): Brave and courageous people do not shrink from threat, challenge, difficulty or pain. They speak up for their opinions and convictions even if there is opposition", or "Perseverance (persistence, industriousness): Persistent and industrious people finish what they start, even despite obstacles. They do not allow themselves to be distracted by inner or outer factors and take pleasure in completing tasks"). The factor structure of the scale was tested. A parallel analysis was performed, and it suggested the extraction of five factors. Afterwards, a Principal Component Analysis (PCA) and a Varimax rotation with Kaiser Normalization were conducted. Five factors were extracted, which could be labelled as interpersonal strengths, intellectual strengths, transcendence strengths, emotional strengths, and strengths of restraint, which was in accordance with previous research (e.g., Ruch et al., 2014). This factor structure (see Table 1) was verified by a Confirmatory Factor Analysis $(\mathrm{CFA}$; RMSEA = .60; CFI $=.925)$.

For subsequent analyses, mean scores of the character strengths pertaining to each of the factors were used. The Cronbach's alphas in the present study were .70 for intellectual strengths, .76 for interpersonal strengths, .63 for emotional strengths, .69 for strengths of restraint and .59 for transcendence strengths, which are similar to the alphas reported by Ruch et al. (2014) $(.74, .83, .75, .62, .53$, respectively) regarding the original version. 
Passion, character strengths and resilience

Table 1

Rotated Component Matrix: Strengths and its Factors.

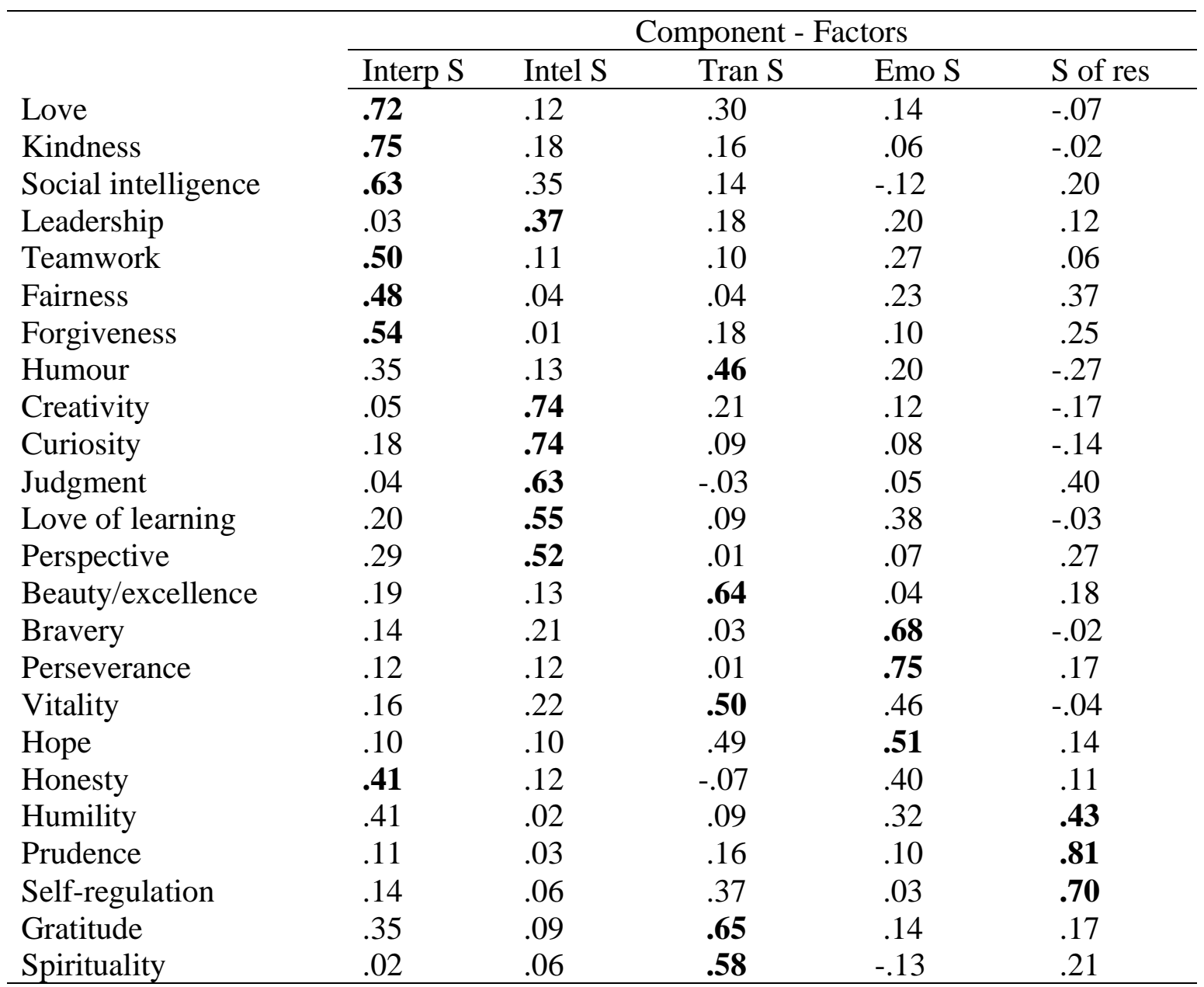

Note. Character strengths belonging to each factor in bold. Beauty/excellence $=$

Appreciation of beauty and excellence. Interp $\mathrm{S}=$ Interpersonal strengths. Intel $\mathrm{S}=$ Intellectual strengths. Tran $=$ Transcendence strengths. Emo $S=$ Emotional strengths. $S$ of res $=$ Strengths of restraint.

The Passion Scale (Marsh et al., 2013; Vallerand et al., 2003). The Spanish version was used (Chamarro et al., 2015). The Passion Scale consists of 17-items with a 7-point Likert-type responses, ranging from $1=$ total disagreement to 7 = total agreement . HP is measured by six items (e.g., "This activity is in harmony with the other activities in my life"), as well as OP (e.g., "I have almost an obsessive feeling for this activity"). Five additional items measure criterion passion to distinguish passionate participants from not passionate ones (e.g., "I like this activity"). The
Cronbach's alphas in the present study were .84 for the total score of the Passion Scale, .74 for HP, .83 for OP and .75 for criterion passion.

The Connor-Davidson Resilience Scale 10-Item (CD-RISC 10-Item; Connor \& Davidson, 2003). The Spanish version, provided by the authors of the scale, was adapted to the sport context by making the instructions sport-oriented (with previous permission from the authors of the scale). Athletes answered 10 items in terms of their frequency of occurrence during the last 


\section{Vančáková, Chamarro, \& Martínez-Martí}

month. If that situation did not occur, they were asked to indicate how they would have reacted if that situation had happened on a 5-point Likerttype scale ranging from $0=$ not true at all to $4=$ true nearly all the time. Sample items are "I can deal with whatever comes my way" or "Under pressure, I stay focused and think clearly".

Additionally, considering that resilience may vary in different contexts (Connor \& Davidson, 2003), we developed five new sport-specific items that reflected important factors for resilience in the sport context. From these five new items, two items assessed adaptation to failure in the sport context (e.g., Fletcher \& Sarkar, 2012; Hosseini \& Besharat, 2010; Stambulova, Stambulov, \& Johnson (2012) (e.g., "I know how to adapt to failure during my training as well as during competition"). Another item evaluated fear of success (Horner, 1972) (i.e., "When I reach my goals, I do not have problems to set myself other goals"). An additional item measured adaptation to success, based on the research on success by Stambulova et al. (2012) (i.e., "I know how to adapt to success during my training as well as during competition"). Finally, the last item evaluated perceived support (Davydov, Stewart, Ritchie, \& Chaudieu, 2010) (i.e., "When I need to ask for help, I know whom to ask"). The alpha value of the 15-item resilience instrument in the present study was .83 .

\section{Procedure}

The data collection was performed between March and November of 2017. Two methods of data collection were used: a paper-and-pencil format (region of Barcelona and Granada) and an on-line format (social networks, e-mails and leaflets with a direct link) through the server www.soscisurvey.de. All respondents signed an informed consent and agreed with participation in the study. Participation was anonymous and voluntary, with no remuneration. The first author collected the paper-and-pencil data, except in one club in which the sport psychologist collected the data and sent the filled questionnaires to the researcher.

The inclusion criteria were being older than 16 years or having expressed permission from the legal representative, signing the informed consent, being passionate about sport, and having filled out almost the entire questionnaire (maximum of four items missing $=5 \%$ ).

\section{RESULTS}

Results of the Kolmogorov-Smirnov test (Table 2) indicated a not normal distribution in all variables. Even if skewness and kurtosis were not large, we decided to compute the Spearman correlation coefficient.

\section{Hypotheses testing \\ Relationship among the variables of the study}

Descriptive statistics and bivariate correlations between the variables of interest are reported in Table 3 (correlations with individual character strengths are reported in Supplementary Material I). Character strengths factors showed moderate positive correlations among one another (with exception of the strengths of restraint and intellectual strengths, which had a small correlation, although still significant). Resilience also yielded moderate positive correlations with all character strengths factors, ranging from $r=$ .30 (strengths of restraint) to $r=.51$ (emotional strengths). HP was positively associated with all factors of character strengths, ranging from $r=$ .19 (strengths of restraint) to $r=.37$ (intellectual strengths), as well as with resilience $(r=.37)$, while OP generally showed no associations with character strengths, except a low positive association with transcendence strengths $(r=.09)$. No significant association was found between OP and resilience. These results reflect the different relationships between the two types of passion and character strengths and resilience. 


\section{Table 2}

Tests of Normality.

\begin{tabular}{llllll}
\hline & \multicolumn{3}{l}{ Kolmogorov-Smirnov } & Skewness & Kurtosis \\
& Statistic & $\mathrm{df}$ & $\mathrm{p}$ & & \\
\cline { 2 - 6 } Harmonious passion & .12 & 393 & $<.001$ & -1.16 & 2.03 \\
Obsessive passion & .05 & 393 & .015 & -.03 & -.74 \\
Resilience & .06 & 393 & .001 & -.29 & -.31 \\
Interpersonal strengths & .10 & 393 & $<.001$ & -.79 & 1.00 \\
Intellectual strengths & .10 & $393<.001$ & -.63 & .39 \\
Transcendence & .08 & $393<.001$ & -.66 & .81 \\
strengths & & & & & \\
Emotional strengths & .13 & $393<.001$ & -.96 & .89 \\
Strengths of restraint & .13 & 393 & $<.001$ & -.92 & .93 \\
\hline
\end{tabular}

Table 3

Descriptive statistics and bivariate correlations.

\begin{tabular}{lcrrllllllll}
\hline & $\mathrm{M}$ & $\mathrm{SD}$ & $\alpha$ & 1 & 2 & 3 & 4 & 5 & 6 & 7 & 8 \\
\hline 1 Interpersonal s. & 7.64 & .81 & .76 & - & $.46^{* *}$ & $.47^{* *}$ & $.41^{* *}$ & $.48^{* *}$ & $.31^{* *}$ & .01 & $.40^{* *}$ \\
2 Intellectual s. & 7.20 & .95 & .70 & - & $.38^{* *}$ & $.44^{* *}$ & $.32^{* *}$ & $.42^{* *}$ & .08 & $.47^{* *}$ \\
3 Transcendence s. & 7.26 & .99 & .59 & & - & $.36^{* *}$ & $.38^{* *}$ & $.29^{* *}$ & $.09^{*}$ & $.37^{* *}$ \\
4 Emotional s. & 7.51 & 1.05 & .63 & & & - & $.37^{* *}$ & $.35^{* *}$ & $.10^{*}$ & $.54^{* *}$ \\
5 S. of restraint & 7.05 & 1.23 & .69 & & & & - & $.23^{* *}$ & .06 & $.34^{* *}$ \\
6 Harmonious P. & 36.67 & 4.26 & .74 & & & & & - & $.20^{* *}$ & $.40^{* *}$ \\
7 Obsessive P. & 23.07 & 8.23 & .83 & & & & & & - & .07 \\
8 Resilience & 45.76 & 6.98 & .83 & & & & & & & - \\
\hline
\end{tabular}

\section{Mediation analyses}

The statistical significance of the mediation effects of the mediation model tested in the study (see Figure 3) was investigated by using the ordinary least squares regression method. Analyses were conducted through SPSS macro
PROCESS 3.4.1 (model 4) (Hayes 2013). We generated 10000 bootstrapped samples to estimate the confidence interval of the model effect. A $95 \%$ confidence interval without zero indicates statistical significance. 


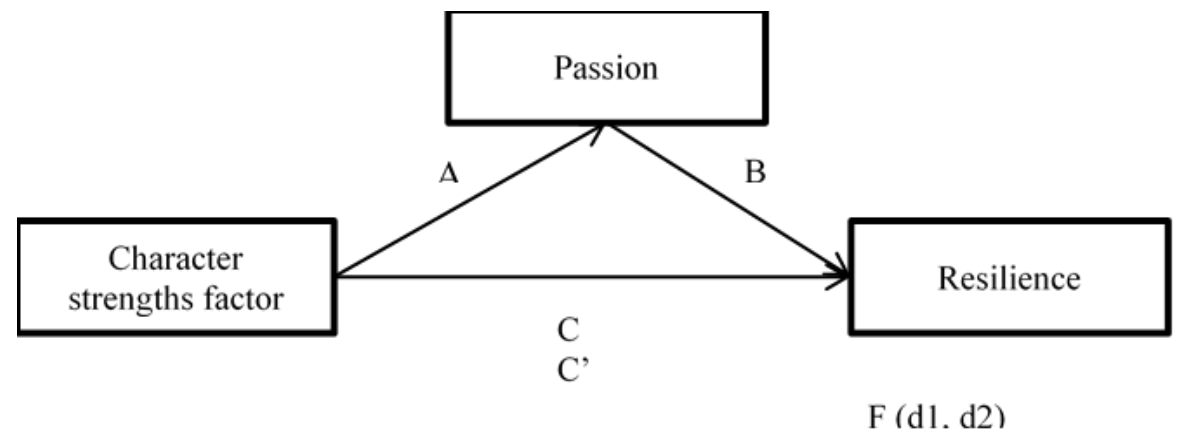

Figure 3. Mediation analysis for character strengths factor, passion, and resilience.

Harmonious passion. The results indicated a significant effect of harmonious passion as a mediator on the relationship between all factors of character strengths and resilience (B path). However, the effect of character strengths on resilience controlling for harmonious passion was also significant (C'path). Therefore, harmonious passion partially mediated the relationship

Table 4

Mediating effect of harmonious passion and obsessive passion on the relationship between character strengths and resilience.

\begin{tabular}{|c|c|c|c|c|c|c|}
\hline & $\begin{array}{l}\text { Effect of CS } \\
\text { on } R\end{array}$ & Effect of CS on P & $\begin{array}{l}\text { Effect of CS } \\
\text { on } R\end{array}$ & $\begin{array}{l}\text { Effect of CS } \\
\text { on R, } \\
\text { Controlling for } \\
\text { P }\end{array}$ & $\begin{array}{l}\text { Mediated effect } \\
\text { significance }\end{array}$ & $\mathrm{F}$ \\
\hline HP & C path & A path & B path & C'path & & \\
\hline Interpersonal S. & $3.46 * *(.36)$ & $1.55 *(.23)$ & $.45^{*}(.07)$ & $2.77 *(.36)$ & $69(.17)[.39,1.09]$ & $91.44 * *$ \\
\hline Intellectual S. & $3.38 * *(.30)$ & $1.68 * *(.19)$ & $.37 * *(.07)$ & $2.75 * *(.31)$ & $.63(.16)[.35, .98]$ & $126.98 * *$ \\
\hline Transcendence $\mathrm{S}$ & $2.69 * *(.30)$ & $1.41 * *(.19)$ & $.45 * *(.07)$ & $2.06 * *(.30)$ & $.63(.15)[.39, .97]$ & $80.84 * *$ \\
\hline Emotional S. & $3.39 * *(.26)$ & $1.29 * *(.18)$ & $.38 * *(.07)$ & $2.90 * *(.27)$ & $.48(.13)[.27, .78]$ & $166.56 * *$ \\
\hline $\begin{array}{l}\text { S. of restraint } \\
\text { OP }\end{array}$ & $1.69 * *(.25)$ & $.65 * *(.16)$ & $.53 * *(.07)$ & $1.35 * *(.24)$ & $.34(.10)[.16, .58]$ & $46.37 * *$ \\
\hline Interpersonal S & $3.46 * *(.36)$ & $.00(.47)$ & $.06(.04)$ & $3.46 * *(.36)$ & $.00(.34)[-.07, .07]$ & $91.44 * *$ \\
\hline Intellectual S. & $3.38 * *(.30)$ & $.66(.40)$ & $.03(.03)$ & $3.36 * *(.30)$ & $.02(.03)[-.01, .11]$ & $126.98 * *$ \\
\hline Transcendence $\mathrm{S}$. & $2.69 * *(.30)$ & $.78 *(.38)$ & $.03(.04)$ & $2.66 * *(.30)$ & $.03(.04)[-.02, .13]$ & $80.84 * *$ \\
\hline Emotional S. & $3.39 * *(.26)$ & $.67(.36)$ & $.03(.03)$ & $3.37 * *(.26)$ & $.02(.03)[-.02, .11]$ & $166.56 * *$ \\
\hline S. of restraint & $1.69 * *(.25)$ & $.30(.31)$ & $.05(.04)$ & $1.68 * *(.25)$ & $.02(.02)[-.01, .10]$ & $46.37 * *$ \\
\hline
\end{tabular}

Note . $\mathrm{HP}=$ Harmonious passion. $\mathrm{OP}=$ Obsessive passion. $\mathrm{CS}=$ Character Strengths. $\mathrm{R}=$ Resilience. $\mathrm{P}=\mathrm{Passion}$. The numbers in parentheses are standard errors. The numbers in brackets are intervals of confidence.

$* \mathrm{p}<.05 . * \mathrm{p}<.001$.

\section{DISCUSSION}

The aim of the present study was to explore the between all factors of character strengths and resilience (Table 4).

Obsessive passion. Obsessive passion did not show a significant effect as a mediator on the relationship between character strengths and resilience. In fact, obsessive passion was not significantly related to neither character strengths factors (except with the factor of transcendence) nor resilience (Table 4). 


\section{Passion, character strengths and resilience}

First, according to our results, all character strengths factors, HP (but not OP), and resilience were positively interrelated in athletes, thus our first hypothesis was accepted. Second, HP (but not OP) partially mediated the relationship between character strengths and resilience in passionate athletes. Therefore, the second hypothesis was accepted too.

The present results are in line with former studies supporting the influence of personality on resilience (e.g., Allen \& Laborde, 2014) and, more specifically, with findings regarding the relationship between character strengths and resilience (Martinez-Martí \& Ruch, 2016). In fact, emotional strengths and intellectual strengths were the two strengths factors that showed the highest correlations with resilience in MartínezMartí and Ruch (2016) study and in the present study. More specifically, the three individual strengths that yielded the highest correlations with resilience in Martínez-Martí and Ruch (2016) study were exactly the same strengths that correlated highest with resilience in the present study, i.e., zest/vitality, hope, and bravery. These results are also consistent with previous theory suggesting that character strengths are positive traits that contribute to adaption (Peterson \& Seligman, 2004) and support recuperation (Seligman, 2003).

The present study explored this relationship for the first time (that we know) in the sport context, which involves numerous challenges and opportunities to cope with difficult situations. Personal resources must be developed to overcome these situations successfully, and character strengths seem to be one of those protective factors. Results showed that the strengths that yielded the highest correlations with resilience in athletes were the same that in a sample of non-athletes (Martínez-Martí \& Ruch, 2016). This result somehow suggests that the relationship between character strengths and resilience is not context-specific, what in some way contradicts the assumption that resilience is context-specific (Connor \& Davidson, 2003).

Regarding the directionality of the relationship between character strengths and resilience in athletes, the present results do not allow to make any inferences on causality. We do not know yet if athletes who have higher scores in bravery, vitality, hope, and resilience are that way as a result of practicing sport regularly, or they were already high in bravery, vitality, hope, and resilience before practicing sport and chose to practice sport regularly because it is a context that allows them to express who they are, i.e., their character strengths, and they feel they can cope with its inherent challenges effectively, i.e., they are resilient in that context. Future longitudinal studies are needed to reveal the specific routes by which these possible relationships might take place.

Regarding the results that show the positive associations of all character strengths factors with harmonious passion (HP), but not with OP, they support the Dualistic Model of Passion (Vallerand et al., 2003). If we consider that character strengths, as positive traits of personality, are part of the athletes' identity, these results reflect that the HP of athletes for sport is fully integrated in their identity.

On the other hand, the positive association between HP and resilience is also in line with former studies showing that HP was more adaptive than OP (Curran et al., 2015; Vallerand, 2015). The differences found between the two types of passion, regarding its differential relationship with resilience, support the duality of this concept. According to Vallerand (2015), both types of passion influence performance positively, but $\mathrm{OP}$ is related with negative outcomes as well (e.g., rumination or negative affect). The lack of relationship between resilience and OP reported in the present study could explain that fact. Likewise, the relationship between HP and resilience might explain why 


\section{Vančáková, Chamarro, \& Martínez-Martí}

individuals high in HP do not experiment these negative outcomes (i.e., negative affect or rumination). In other words, individuals high in $\mathrm{HP}$ are more resilient and, therefore, are protected from those negative outcomes. The partial mediating role of HP on the effect of character strengths on resilience confirms the importance of this concept for athletes. It suggests that a possible way to enhance the resilience of athletes could be to focus on the development of both character strengths and HP.

Regarding the limitations of the study, we have already mentioned that this study is crosssectional and prevents from inferring any causality between the variables explored. Moreover, the study relied exclusively on selfreport measures. Future studies including more objective measures would be desirable. Another limitation is the representativeness of the sample and generality of the results to other populations of athletes. We tried to collect data from athletes of different sports, with different degrees of sport dedication, within a large range of age, and both men and women, in order to have a rich and varied sample, although still not representative of the population. Therefore, the results of this study should not be generalized to all athletes but interpreted within its limitations. Finally, the reliability of two dimensions of character strengths is below the minimums considered acceptable. Even if these values are acceptable for use in research, it should be considered that this may limit their usefulness in applied contexts.

\section{PRACTICAL IMPLICATIONS}

The present study has the next implications. It provides original evidence regarding the relationship between character strengths, passion, and resilience in the sport context, expanding the current knowledge in this area. The results suggest that both character strengths and harmonious passion could be important contributors to resilience in athletes and pave the way for future studies aiming at designing positive interventions in the sport context, which are still in an incipient state. Emotional strengths (such as bravery, perseverance, and hope) and intellectual strengths (such as creativity, curiosity, and judgement/critical thinking) appear to be, as in previous studies (Martínez-Martí \& Ruch, 2016), good candidates for interventions aimed at increasing resilience. We propose the development of strength-based interventions, oriented to nourish harmonious passion, to increase the resilience of athletes. Considering that character strengths can be learned, changed by experience and volition (Peterson \& Seligman, 2004), the findings of the present study reinforce the value of character strengths as a source of resilience and adaptation to stress that athletes can develop. These recommendations are in line with proposals of developing resilience using coping strategies focused on the task (Secades, Molinero, Salguero et al., 2016; Secades, Molinero, RuizBarquín et al., 2017) and promoting preventive character strength interventions in adverse situations (Martínez-Martí et al., 2020).

\section{REFERENCES}

1. Allen, M. S., \& Laborde, S. (2014). The Role of Personality in Sport and Physical Activity. Current Directions in Psychological Science, 23(6), 460-465. https://doi.org/10.1177/09637214145507 05

2. Ato, M., López, J. J., \& Benavente, A. (2013). Un sistema de clasificación de los diseños de investigación en psicología. Anales de Psicología, 29(3), 1038-1059. https://doi.org/10.6018/analesps.29.3.178 511

3. Chamarro, A., Penelo, E., Fornieles, A., Oberst, U., Vallerand, R. J., \& FernándezCastro, J. (2015). Psychometric properties of the Spanish version of the Passion Scale. Psicothema, 27(4), 402-409. https://doi.org/10.7334/psicothema2015.8 0 


\section{Passion, character strengths and resilience}

4. Chamorro, J. L., Moreno, R., GarcíaCalvo, T., \& Torregrossa, M. (2020). The Influence of Basic Psychological Needs and Passion in Promoting Elite Young Football Players' Development. Frontiers in Psychology, 11(November). https://doi.org/10.3389/fpsyg.2020.57058 4

5. Connor, K. M., \& Davidson, J. R. T. (2003). Development of a new resilience scale: The Connor-Davidson Resilience Scale (CD-RISC). Depression and Anxiety, 18(2), 76-82. https://doi.org/10.1002/da.10113

6. Curran, T., Hill, A. P., Appleton, P. R., Vallerand, R. J., \& Standage, M. (2015). The psychology of passion: A metaanalytical review of a decade of research on intrapersonal outcomes. Motivation and Emotion, 39(5), 631-655. https://doi.org/10.1007/s11031-0159503-0

7. Davydov, D. M., Stewart, R., Ritchie, K., \& Chaudieu, I. (2010). Resilience and mental health. Clinical Psychology Review, 30(5), 479-495. https://doi.org/10.1016/j.cpr.2010.03.003

8. Dubreuil, P., Forest, J., Gillet, N., Fernet, C., Thibault-Landry, A., Crevier-Braud, L., \& Girouard, S. (2016). Facilitating well-being and Performance through the Development of Strengths at Work: Results from an Intervention Program. International Journal of Applied Positive Psychology, 1(1-3), 1-19. https://doi.org/10.1007/s41042-0160001-8

9. Fletcher, D., \& Sarkar, M. (2012). A grounded theory of psychological resilience in Olympic champions. Psychology of Sport and Exercise, 13(5), 669-678.

https://doi.org/ 10.1016/j.psychsport.201 2.04 .007

10. Fletcher, D., \& Sarkar, M. (2013). Psychological Resilience: A Review and
Critique of Definitions, Concepts and Theory. European Psychologist, 18, 1223. https://doi.org/0.1027/10169040/a000124

11. Forest, J., Mageau, G. A., Crevier-Braud, L., Bergeron, É., Dubreuil, P., \& Lavigne, G. L. (2012). Harmonious passion as an explanation of the relation between signature strengths' use and well-being at work: Test of an intervention program. Human Relations, 65(9), 1233-1252. https://doi.org/10.1177/00187267114331 34

12. Galli, N., \& Vealey, R. S. (2008). "Bouncing back" from adversity: Athletes' experiences of resilience. Sport Psychologist, 22(3), 316-335. https://doi.org/10.1123/tsp.22.3.316

13. García Secades, X., Molinero, O., Ruíz Barquín, R., Salguero, A., Vega, R. de la, \& Márquez, S. (2014). La resiliencia en el deporte: fundamentos teóricos, instrumentos de evaluación y revisión de la literatura. Cuadernos de Psicología del Deporte, 14(3), 83-98. https://doi.org/10.4321/S157884232014000300010

14. Gousse-Lessard, A. S., Vallerand, R. J., Carbonneau, N., \& Lafrenière, M. A. K. (2013). The role of passion in mainstream and radical behaviors: A look at environmental activism. Journal of Environmental Psychology, 35, 18-29. https://doi.org/10.1016/j.jenvp.2013.03.0 03

15. Hayes, A. F. (2013). Introduction to mediation, moderation and conditional process analysis. A regression based approach. Nueva York: The Guilford Press.

16. Horner, M. S. (1972). Toward an understanding of achievement-related conflicts in women. Journal of Social issues, 28(2), 157-175. https://doi.org/10.1111/j.15404560.1972.tb00023.x 


\section{Vančáková, Chamarro, \& Martínez-Martí}

17. Hosseini, S. A., \& Besharat, M. A. (2010). Relation of reilience with sport achievement and mental health in a sample of athletes. Procedia Social and Behavioral Sciences, 5(2), 633-638. https://doi.org/10.1016/j.sbspro.2010.07. 156

18. Jordan, J. V. (2005). Relational resilience in girls. In E. Goldstein \& Brooks, R. B. (Eds.), Handbook of resilience in children (pp. 91-105). New York: Springer.

19. Luthar, S. S., Cicchetti, D., \& Becker, B. (2000). The Construct of Resilience: A Critical Evaluation and Guidelines for Future Work. Child Development, 71(3), 543-62. https://doi.org/ 10.1111/14678624.00164

20. Marsh, H. W., Vallerand, R. J., Lafrenière, M.A. K., Parker, P., Morin, A. J. S., Carbonneau, N., Jowett, S., Bureau, J. S., Fernet, C., Guay, F., Salah Abduljabbar, A., \& Paquet, Y. (2013). Passion: Does one scale fit all? Construct validity of twofactor passion scale and psychometric invariance over different activities and languages. Psychological Assessment, 25(3), 796-809. https://doi.org/10.1037/a0032573

21. Martínez-Martí, M. L., \& Ruch, W. (2016). Character strengths predict resilience over and above positive affect, self-efficacy, optimism, social support, self-esteem, and life satisfaction. The Journal of Positive Psychology, 12(2), 110-119.

https://doi.org/ 10.1080/17439760.2016.1 163403

22. Martínez-Martí, M. L., Theirs, C. I., Pascual, D., \& Corradi, G. (2020). Character Strengths Predict an Increase in Mental Health and Subjective Well-Being Over a One-Month Period During the COVID-19 Pandemic Lockdown. Frontiers in Psychology, 11, 584567. https://doi.org/10.3389/fpsyg.2020.58456 7
23. Niemiec, R. M. (2018). Character Strengths Interventions: A Field Guide for Practitioners. Göttingen, Germany: Hogrefe Publishing.

24. Peterson, C., \& Seligman, M. E. P. (2004). Character strengths and virtues: A handbook and classification. New York, NY: Oxford University Press and Washington, DC: American Psychological Association.

25. Peterson, C., Park, N., \& Seligman, M. E. P. (2006). Greater strengths of character and recovery from illness. The Journal of Positive Psychology, 1, 17-26. https://doi.org/ 10.1080/17439760500372739

26. Raimundi, M. J., García Arabehety, M., Iglesias, D., \& Castillo, I. (2018). Aspiraciones vitales y su relación con la pasión en deportistas argentinos seleccionados para los Juegos Olímpicos de la Juventud. Cuadernos de Psicología del Deporte, 19(1), 192-205. https://doi.org/10.6018/cpd.339431

27. Rip, B., Fortin, S., \& Vallerand, R. J. (2006). The relationship between passion and injury in dance students. Journal of Dance, Medicine \& Science, 10(1-2), 1420.

28. Roffé, M. (2016). La preparación psicológica de la Selección Nacional Absoluta de Colombia para el Mundial de Fútbol Brasil 2014. Revista de Psicología Aplicada al Deporte y el Ejercicio Físico, 1(1), $\quad 1-7$. https://doi.org/10.5093/rpadef2016a3

29. Ruch, W., Martínez-Martí, M. L., Proyer, R. T., \& Harzer, C. (2014). The Character Strengths Rating Form (CSRF): Development and initial assessment of a 24-item rating scale to assess character strengths. Personality and Individual Differences, 68, 53-58. https://doi.org/10.1016/j.paid.2014.03.04 2 


\section{Passion, character strengths and resilience}

30. Ruiz, R., De La Vega, R., Poveda, J., Rosado, A., \& Serpa, S. (2012). Análisis psicométrico de la escala de resiliencia en el deporte del fútbol. Revista de Psicologia del Deporte, 21(1), 143-151. https://doi.org/10.1016/s18887546(12)70006-0

31. Sarkar, M., \& Fletcher, D. (2013). How Should We Measure Psychological Resilience in Sport Performers? Measurement in Physical Education and Exercise Science, 17(4), 264-280. https://doi.org/10.1080/1091367X.2013.8 05141

32. Sarkar, M. \& Fletcher, D. (2014). Psychological resilience in sport performers: A review of stressors and protective factors. Journal of Sport Sciences, 32, 1419-1434. https://doi.org/10.1080/02640414.2014.9 01551

33. Secades, X. G., Molinero, O., Salguero, A., Barquín, R. R., de la Vega, R., \& Márquez, S. (2016). Relationship Between Resilience and Coping Strategies in Competitive Sport. Perceptual and Motor Skills, 122(1), 336-349. https://doi.org/10.1177/00315125166310 56

34. Secades, X. G., Molinero, O. R., RuizBarquín, R., Salguero, A., De la Vega, R., \& Màrquez, S. (2017). Resilience and recovery-stress in competitive athletes. Cuadernos de Psicología del Deporte, 17, 73-80.

35. Seligman, M. E. P. (2003). Positive psychology: Fundamental assumptions. The Psychologist, 16(3), 126-127.

36. Stambulova, N., Stambulov, A., \& Johnson, U. (2012). "Believe in Yourself, Channel Energy, and Play Your Trumps": Olympic preparation in complex coordination sports. Psychology of Sport and Exercise, 13(5), 679-686. https://doi.org/10.1016/j.psychsport.2012 .04 .009
37. Stenseng, F., Forest, J., \& Curran, T. (2015). Positive Emotions in Recreational Sport Activities: The Role of Passion and Belongingness. Journal of Happiness Studies, 16(5), 1117-1129. https://doi.org/10.1007/s10902-0149547-y

38. Trépanier, S. G., Fernet, C., Austin, S., Forest, J., \& Vallerand, R. J. (2014). Linking job demands and resources to burnout and work engagement: Does passion underlie these differential relationships? Motivation and Emotion, 38(3), 353-366. https://doi.org/10.1007/s11031-0139384-z

39. Vallerand, R. J. (2015). The psychology of passion: A dualistic model. New York: Oxford.

40. Vallerand, R. J., Blanchard, C., Mageau, G. A., Koestner, R., Ratelle, C., Léonard, M., Gagné, M., Marsolais, J. (2003). Les passions de l'Ame: On obsessive and harmonious passion. Journal of Personality and Social Psychology, 85(4), 756-767. https://doi.org/ 10.1037/00223514.85.4.756

41. Vallerand, R. J., \& Miquelon, P. (2007). Passion for Sport in Athletes. In S. Jowette \& D. Lavallee (Eds.), Social Psychology in Sport (pp. 249-263). Champaign, IL, US: Human Kinetics.

42. Wagstaff, C. R. D., Sarkar, M., Davidson, C. L., \& Fletcher, D. (2017). Resilience in sport: A critical review of psychological processes, sociocultural influences, and organizational dynamics. In C. R. D. Wagstaff (Ed.), The organizational psychology of sport: Key issues and practical applications (pp. 120-149). New York, NY, US: Routledge/Taylor \& Francis Group.

43. Wong, P. T. P. (1995). A stage model of coping with frustrative stress. In R. Wong (Ed.), Biological perspectives on 


\section{Vančáková, Chamarro, \& Martínez-Martí}

motivated activities (pp. 339-378). Westport, CT, US: Ablex Publishing.

44. Young, B. W., de Jong, G. C., \& Medic, N. (2015). Examining relationships between passion types, conflict and negative outcomes in masters athletes. International Journal of Sport and Exercise Psychology, 13(2), 132-149. https://doi.org/10.1080/1612197X.2014.9 32822
45. Zautra, A. J., \& Reich, J. W. (2012). Resilience: The Meanings, Methods, and Measures of a Fundamental Characteristic of Human Adaptation. In The Oxford Handbook of Stress, Health, and Coping. Oxford University Press. https://doi.org/10.1093/oxfordhb/978019 5375343.013.0009 